\title{
ДЕЙСТВИЕ МЕЖДУНАРОДНЫХ ДОГОВОРОВ В СФЕРЕ ОХРАНЫ ОКРУЖАЮЩЕЙ СРЕДЫ В НАЦИОНАЛЬНОМ ПРАВЕ СТРАН СЕВЕРНОЙ ЕВРОПЫ
}

\begin{abstract}
Аннотация. В данной статье рассмотрены способы придания международным обязательствам в сфере охраны окружающей среды нормативной силь в национальных правовых системах Норвегии, Финляндии и Швечии. Рассматривается как влияние международного так и европейского права в сфере охраны окружающей среды на законодательство скандинавских государств. Рассматриваются прочедурные и материальные вопросы имплементации норм международного права в сфере охраны окружающей среды на национальное законодательство рассматриваемых государств. Утверждается, создание международного сотрудничества в рамках одного региона является довольно простым даже в такой сфере как защита окружающей среды. Также отмечено, что международно-правовая защита окружающей среды в рамках рассмотренных международных договоров скандинавских стран имеет характер наднациональности. Рассмотрено взаимодействие европейского права с международным на примере взаимодействия европейского законодательства в сфере охраны окружающей среды и международно-правовых обязательств скандинавских государств. Ключевые слова: Международное право, европейское право, национальное законодательство, окружающая среда, имплементация, ратификация, международно-правовые обязательства, кодификаџия, скандинавские страны, экологическое право
\end{abstract}

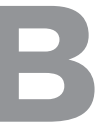
целях решения вопроса о соотношении международного и национального права государства в своих конституциях или иных нормативных правовых актах закрепляют положения, которые определяют юридическую силу международных договоров и их применимость в рамках национального права, регулируют порядок заключения, денонсации и исполнения международных договоров.

В одних государствах международный договор становится частью национального права в силу признания примата международного права, на котором основываются национальные суды при разрешении споров (США, Франция, Бельгия, Нидерланды, Швейцария, Литва и др.). В других государствах принимаются нормативные акты, отражающие положения международного договора в национальном праве, используя более точные термины и адаптируя их к специфике своих внутренних законодательств. Например, в ряде стран восприятие норм международных договоров происходит путем принятия специального правового акта, например, закона, в котором воспроизводятся положения договора, акта об обнародовании и т. п. (Великобритания, Канада, Израиль и др.). ${ }^{1}$

В отечественной доктрине международного права признается плодотворной концепция «материально-правовой трансформации», поскольку позволяет противопоставить «кельзианскому 'монизму' действенную дуалистическую концепцию»². В рамках этой концепции выделяются генеральная и специальная трансформация. Первая представляет собой конституционную, обычно-правовую или законодательную норму, предусматривающую то, что международное право в целом или частично является частью национального права данного государства.

Специальная трансформация может осуществляться путем отсылки, рецепции, инкорпорации

\footnotetext{
${ }^{1}$ См.: Ногойбаева Э.К. Механизм реализации международных договоров и норм международного права в Кыргызской Республике // AUCA Academic Review. 2009. C. 84.

${ }^{2}$ См.: Усенко E.T. Очерки теории международного права. М.: Норма, 2008. С. 141.
} 
или воспроизведении нормы международного права в актах национального права. Несмотря на большое количество подходов к способам трансформации, суть ее не меняется, поскольку речь идет о придании норме международного права внутригосударственного действия. ${ }^{3}$ Не только в теории права, но и на практике отмечается, что для выполнения международных обязательств нередко требуется принятие внутригосударственных актов, хотя непосредственно не связанных с трансформацией международно-правовой нормы, но необходимых для доведения соответствующих правил до непосредственных исполнителей. ${ }^{4}$

Следует учитывать, что принятые различными договаривающимися государствами в целях исполнения одного и того же договора нормы «бывают несходными не только формально, но часто и материально» ${ }^{5}$. В этой связи представители юридической доктрины солидарны в том, что международное право налагает обязательство, «нацеленное на результат, а не на средства его достижения. Государства в целом свободны в установлении порядка и выборе способов реализации международных договорных обязательств» ${ }^{6}$.

Под эгидой Комитета юридических советников по международному публичному праву Совета Европы в 2001 году был подготовлен специальный доклад 7 , отражающий собственное видение государствами процедур трансформации международного права в национальные системы. Аналитические материалы относительно трансформации международных обязательств были представлены, в том числе, Норвегией ${ }^{8}$,

${ }^{3}$ См.: Усенко E.T. Очерки теории международного права. М.: Норма, 2008. С. 143; Черниченко С.В. Международное право: учеб. - 3-е изд., перераб. и доп. М.: ТК Велби, Изд-во Проспект, 2008. С. $84-89$.

${ }^{4}$ См.: Усенко Е.T. Очерки теории международного права. М.: Норма, 2008. С. 143.

${ }^{5}$ См.: Анцилотти Д. Курс международного права Т. 1. М., 1961. С. 350.

${ }^{6}$ Осминин Б.И. Принятие и реализация государствами международных договорных обязательств. М.: Волтерс Клувер, 2006. С. 6. См. также: Морозов А.Н. Реализация международных договоров в Российской Федерации: правовые основания // Журнал российского права. 2009. № 2 . С. 100 - 110.

${ }^{7}$ Treaty Making - Expression of Consent by States to be Bound by a Treaty. Hague: Walters Kluwer, 2001. - 349 p.

${ }^{8}$ CM.: Country Reports. Norway // Treaty Making - Expression of Consent by States to be Bound by a Treaty. Hague, 2001. P. 174-176.
Финляндией ${ }^{9}$ и Швецией ${ }^{10}$. Согласно материалам указанного Доклада, все государства был отнесены к трем группам в зависимости от способа реализации международных договорных обязательств в национальной правовой системе.

Первую группу составляют государства, реализующие международные обязательства посредством материальной инкорпорации. В нее входят государства Британского содружества, Ирландия, Израиль (Вестминстерская модель), а также Норвегия, Дания и Швеция (Скандинавская модель). Включение государства в данную группу означает, что в целях придания положениям международных договоров силы норм национального права требуется воспроизведение в национальных нормативных правовых актах норм международного договора.

Вторую группу составляют государства, реализующие международные обязательства посредством формальной (процедурной) инкорпорации. Это означает, что обязательным условием трансформации положений международного договора в национальную правовую систему является принятие имеющего процессуальный характер акта законодательной или исполнительной власти. К таким странам относятся Германия, Австрия, Италия, Греция, Финляндия и Япония.

К третьей (самой многочисленной) группе отнесены государства, международные договоры которых «автоматически» становятся частью национальной правовой системы (в том числе Англия, США, Россия) (то есть посредством генеральной трансформации $\left.{ }^{11}\right)$.

Компетенция выражать согласие на обязательность международных договоров для

\footnotetext{
${ }^{9}$ Cм.: Country Reports. Finland // Treaty Making - Expression of Consent by States to be Bound by a Treaty. Hague, 2001. P. $125-127$.

${ }^{10}$ CM.: Country Reports. Sweden // Treaty Making - Expression of Consent by States to be Bound by a Treaty. Hague, 2001. P. $205-207$.

${ }^{11}$ См.: Осминин Б.И. Принятие и реализация государствами международных договорных обязательств. М.: Волтерс Клувер, 2006. С. 2 - 3, 64 - 65, 118 - 119. О различиях фактического действия норм международного права воспринятых правом разных стран посредством генеральной трансформации см. в: Усенко E.T. Очерки теории международного права. M., 2008. C. $153-168$.
} 
Норвегии принадлежит королю Норвегии в силу $\S 26$ Конституции Норвегии. При этом «соглашения по вопросам особой важности, и во всех случаях, по делам для которых в соответствии с Конституцией, необходимо принятие нового закона или решения Стортингом, вступают в силу после одобрения Стортингом» ${ }^{12}$. Отечественные специалисты в области права Скандинавских стран отмечают, что решение вопроса о принадлежности договора к категории «особо важный» и, следовательно, необходимости получить его одобрение Стортингом, зависит от оценки Государственного Совета (правительства) ${ }^{13}$. Решения о заключении международных договоров, не относящихся к особо важным, и не требующих изменения существующего или издания нового законодательного акта Стортингом, подготавливаются Государственным Советом без участия Стортинга. В последнем случае решение принимается в форме королевского декрета.

Трансформация международных договорных обязательств в национальное право Норвегии осуществляется посредством материальной инкорпорации. В Норвегии это реализуется посредством принятия законодательных актов Стортингом. Такие акты содержат нормы, соответствующие правилам, содержащимся в международных договорах, участником которых становится Норвегия. В национальном праве юридическую силу имеют только нормы, содержащиеся в актах, посредством которых осуществлена инкорпорация ${ }^{14}$. Поэтому положения международных договоров могут применяться во внутригосударственной сфере только в двух случаях. Во-первых, если положения международных договоров инкорпорированы в национальное законодательство после того, как выражено согласие на его обязательность. Во-вторых, если реализация междуна-

\footnotetext{
${ }^{12}$ Kongeriget Norges Grundlov, given i Rigsforsamlingen på Eidsvold den 17de Mai 1814. Текст Конституции Норвегии цитируется по изданию: Конституция Норвегии (с поправками на 23 июля 1995) (электронный ресурс: http://www.norge.ru/ constitusia/).

${ }^{13}$ См.: Осминин Б.И. Принятие и реализация государствами международных договорных обязательств. М., 2008. С. 59.

${ }^{14}$ См.: Country Reports. Norway // Treaty Making - Expression of Consent by States to be Bound by a Treaty. Hague, 2001. P. $174-176$.
}

родных договоров может быть осуществлена на основе действующего законодательства ${ }^{15}$.

Показателен в этом смысле опыт Норвегии по реализации средствами национального права международных обязательств в сфере охраны окружающей среды. В 1999-2000 годах в рамках Организации по экономическому сотрудничеству и развитию (ОЭСР) была проведена оценка выполнения Норвегией международных обязательств в сфере охраны окружающей среды. В итоговом отчете было указано на необходимость повышения эффективности реализацией Норвегии экологической политики и экологического законодательства, в том числе в сфере снижения загрязнения и усиления охраны природы ${ }^{16}$.

В этой связи 20 апреля 2001 года на основании королевского декрета была создана комиссия из 16 человек, которая в течение трех лет готовила предложения по внесению изменений в национальное законодательство, обеспечивающих выполнение Норвегией своих обязательств из международных договоров в сфере охраны окружающей среды. В ходе работы были оценены, в том числе, географические условия всего региона, риски биоразнообразию, способы их снижения, существующие механизмы в национальном праве, опыт Финляндии, Швеции и Дании, действующие международные договоры и нормативные акты ЕС, экономические последствия. Результаты работы указанной комиссии был изложены в Официальном отчете Норвегии ${ }^{17} 2004$ года № $28^{18}$, представленном в Департамент охраны окружающей среды. На основании указанного отчета в 2008 году было разработано предложение правительства Норвегии Стортингу о принятии Закона об охране природного разнообразия ${ }^{19}$,

\footnotetext{
${ }^{15}$ См.: Осминин. Указ. соч. С. 61.

${ }^{16}$ CM.: OECD Environmental Performance Reviews : Norway. OECD, 2001. P. 20.

${ }^{17}$ Правительство или министерство может создавать комитеты или рабочие группы, призванные изучть тот или иной вопрос. Отчет может иметь статус Официального отчета Норвегии (NOU) или отчета без официального статуса. - Прим. автора.

${ }^{18}$ Lov om bevaring av natur, landskap og biologisk mangfold (Naturmangfoldloven) Norges offentlige utredninger (NOU) 2004: 28. Oslo, 2004. - 839 s.

${ }^{19} \mathrm{Om}$ lov om forvaltning av naturens mangfold (naturmangfoldloven). Ot.prp. nr. 52 (2008-2009). Oslo: Akademika AS, 2008. $-479 \mathrm{~s}$.
} 
который был принят 19 июня 2009 года ${ }^{20}$. В 2009 2010 годах в рамках Организации по экономическому сотрудничеству и развитию (ОЭСР) была проведена очередная оценка выполнения Норвегией международных обязательств в сфере охраны окружающей среды, которая дала высокую оценку нормативного обеспечения реализации указанных обязательств ${ }^{21}$.

Отметим при этом, что правило о материальной инкорпорации положений международных договоров в сфере охраны окружающей среды в норвежское национальное право может иметь исключения. Так, например, в соответствии c $\S 40$ Закона об охране природного разнообразия 2009 года ${ }^{22}$ Король может наделять особо охраняемые территории специальным статусом, предусмотренным конвенциями об охране природных и культурных ценностей. Придание такого статуса особо охраняемой территории означает придание правилам международных договоров, относящихся к таким территориям, такой же силы, как и законам Норвегии.

Соглашения с другими государствами или с международными организациями от имени Королевства Швеция в соответствии с § 1 Главы 10 Формы правления (конституции) Швеции заключаются Правительством. В соответствии с частью 1 § 2 Главы 10 Правительство не может заключать международное соглашение, налагающее на государство обязательство, без ратификации его Риксдагом, если соглашение предусматривает изменение или отмену закона либо издание нового закона либо если оно в иных случаях затрагивает вопрос, решение по которому должен принимать Риксдаг. Правительство не может и в иных случаях, помимо указанного в части 1 § 2 Формы правления, заключать международное соглашение, налагающее на государство обязательство, без ратификации его Риксдагом, если это соглашение имеет важное значение. Правительство вправе, однако, не запрашивать

\footnotetext{
${ }^{20}$ LOV-2009-06-19-100 Naturmangfoldloven - nml. Lov om forvaltning av naturens mangfold (naturmangfoldloven).

${ }^{21}$ CM.: OECD Environmental Performance Reviews: Norway, 2011. OECD Publishing, 2011. $-202 \mathrm{p}$.

${ }^{22}$ LOV 2009-06-19 nr 100: Lov om forvaltning av naturens mangfold (naturmangfoldloven) (электронный ресурс http://www.lovdata.no/all/hl-20090619-100.html).
}

Риксдаг о ратификации соглашения, когда этого требуют интересы государства. В таком случае Правительство должно вместо указанной выше процедуры провести до заключения соглашения обсуждение с Внешнеполитическим комитетом. Важно отметить, что на основании $\S 3$ Главы 10 Формы правления Правительство вправе делегировать право на заключение международного соглашения, по которому не требуется участие Риксдага или Внешнеполитического комитета, органу управления. ${ }^{23}$

Трансформация международных договорных обязательств в национальное право Швеции осуществляется путем материальной инкорпорации посредством принятия законодательных актов Риксдагом. Такие акты содержат нормы, соответствующие правилам, содержащимся в международных договорах, участником которых становится Швеция. В отличие от Норвегии, где в юридическую силу имеют только нормы, содержащиеся в актах, посредством которых осуществлена инкорпорация, в Швеции могут использоваться различные методы. Во-первых, могут изменяться нормы действующих законов или актов административного характера. Во-вторых, возможно закрепление отсылочной нормы в национальном акте о том, что международный договор или его положения должны иметь силу национального закона ${ }^{24}$.

Внешнюю политику Финляндии возглавляет Президент Республики во взаимодействии с Государственным Советом. Однако Эдускунта ${ }^{25}$

\footnotetext{
${ }^{23}$ См. подроб: Осминин Б.И. Принятие и реализация государствами международных договорных обязательств. М., 2008. С. 49 - 50; Конституция Швеции (Форма правления). Принята 27 февраля 1974 г. / Пер. со шведского М.А. Могуновой. М., 1999. C. $696-697$.

${ }^{24}$ Cм.: Country Reports. Sweden // Treaty Making - Expression of Consent by States to be Bound by a Treaty. Hague, 2001. P. 207.

25 Эдускунта - это традиционный для российской юридической литературы термин, обозначающий высший орган представительной власти Республики Финляндия (см.: Могунова М.A. Вводная статья к Форме правления Финляндии от 17 июля 1919 года // Конституции государств Европейского Союза / Под общ. ред. Л.А. Окунькова. М.: Норма - Инфра-М, 1999. С. 603 - 612). Министерство юстиции Финляндии при переводе нового основного закона на русский язык, принятого в 1999 г., предпочло использовать термин «Парламент» (см.: Конституция Финляндии (принята в г. Хельсинки 11 июня 1999 года). Хельсинки: Министерство юстиции, 1999. 35 с.). - Прим. автора.
} 
принимает решения о принятии международных обязательств и их денонсации, а также о введении в действие международных обязательств в части, предусмотренной Основным законом. Государственный Совет обеспечивает национальную подготовку решений, принимаемых в Европейском Союзе, и принимает решения о вытекающих из них мероприятиях Финляндии в случаях, когда не требуется решения Эдускунты. Эдускунта участвует в национальной подготовке принимаемых в Европейском Союзе решений в соответствии с тем, что установлено Конституцией 1999 г. ${ }^{26}$. Сообщение иным государствам и международным организациям внешнеполитических значительных позиций возлагается на министра, к ведению которого отнесены международные отношения (§ 93). Эдускунта принимает международные договоры и иные международные обязательства, входящие в сферу законодательства или имеющие важное значение либо требующие согласно Конституции принятия Эдускунтой (§ 94).

Входящие в сферу законодательства предписания международного договора и иных международных обязательств Финляндии вводятся в действие законодательным актом. Законопроект о введении в действие международного обязательства рассматривается в порядке рассмотрения обыкновенного закона. Иные международные обязательства вводятся в действие указами Президента (§ 95). Президент Республики принимает свои решения на заседании Государственного Совета по предложению последнего (§ 58). Каждый министр, участвовавший в рассмотрении вопроса в Государственном Совете, несет ответственность за решение, насколько им не было заявлено особого мнения для занесения в протокол (§ 60).

Необходимо обратить внимание на то, что Финляндия в своем отчете заявила, что

\footnotetext{
26 Традиционно основной закон Республики Финляндия именовался отечественными специалистами «форма правления» по аналогии со шведским аналогом основного закона (см.: Форма правления Финляндии. Принята 17 июля 1919 г. / Пер. с финского М.А. Могуновой. М.: Норма - Инфра-М, 1999. С. 613 - 628). Министерство юстиции Финляндии при переводе нового основного закона на русский язык, принятого в 1999 г., предпочло использовать термин «конституция» (см.: Конституция Финляндии (принята в г. Хельсинки 11 июня 1999 года). Хельсинки: Министерство юстиции, 1999. 35 с.). - Прим. автора.
}

Президент может делегировать свои полномочия по принятию международных обязательств Государственному совету, уполномоченному министру или иному должностному лицу на основании акта Парламента ${ }^{27}$. Отметим, что на основании § 128 Конституции 1999 г. управленческие функции публичного характера на основании закона или в соответствии с законом (и если это необходимо для целесообразного выполнения функций и не создает угрозу основным правам, правовой защите или иным требованиям к хорошему управлению) могут быть переданы субъектам, не являющимся органами публичной власти.

Инкорпорация положений международных договоров в национальное право Финляндии может осуществляться тремя способами. Вопервых, посредством принятия законодательного акта, которым вносятся изменения в действующие законы или вводятся новые нормы, отражающие соответствующие положения международных договоров. Во-вторых, санкционирование внутригосударственного применения положений международных договоров, которым посредством такого санкционирования придается сила норм национального права. В-третьих, возможно использование комбинации средств, присущих двум указанным выше способам. ${ }^{28}$ Использование таких способов дает основание отечественным специалистам сделать вывод о том, что для Финляндии при трансформации международных договоров в национальное право характерно сочетание материальной и формальной (процедурной) инкорпорации ${ }^{29}$.

Отметим, что законы, посредством которых осуществляется инкорпорация положений международных договоров, в Норвегии, Финляндии и Швеции, имеют тот же статус, что и другие законы $^{30}$, принимаемые органами законодательной власти и по силе действия уступают положениям

\footnotetext{
${ }^{27}$ CM.: Country Reports. Finland // Treaty Making - Expression of Consent by States to be Bound by a Treaty. Hague, 2001. P. 125.

${ }^{28}$ CM.: Country Reports. Finland // Treaty Making - Expression of Consent by States to be Bound by a Treaty. Hague, 2001. P. 127.

${ }^{29}$ См.: Осминин Б.И. Принятие и реализация государствами международных договорных обязательств. М., 2008. С. 110.

${ }^{30}$ См.: C. The relationship between international and domestic law. CDL-STD (1993)006. Strasbourg, 1993. P. 11.
} 
конституций. В этой связи в литературе отмечается, что инкорпорированные в национальное право положения международных договоров в силу принципа lex posterior derogat priori имеют приоритет перед принятыми ранее законами, но принятые впоследствии законодательные акты могут оказывать воздействие на выполнение договорных обязательств в случаях, если закон, инкорпорирующий международный договор, будет отменен или изменен другим законом того же уровня. ${ }^{31}$

Хотя формально указанные страны не признают примат международных договоров перед нормами национального права, они, по мнению С. Экономидеса, «фактически признают это и предпринимают различные меры для недопущения несоответствия национального законодательства положениям международных договоров $»^{32}$. В странах Северной (Европы Дания, Финляндия, Норвегия и Швеция) такой мерой является интерпретация законов органами власти (и особенно судами) образом, обеспечивающим его соответствие международным договорам. Таким образом государства выражают свою приверженность международным обязательствам и обеспечивают их выполнение средствами национального права. ${ }^{33}$

Таким образом, законодательство ни одной из рассматриваемых нами здесь стран (Норвегия, Финляндия, Швеция) не предусматривает автоматической трансформации международных договоров в национальное право без процедур инкорпорации, что свидетельствует доминировании прагматичного подхода к выполнению международных обязательств.

Отдельного внимания заслуживает вопрос о влиянии на национальное право Норвегии, Финляндии и Швеции нормативных актов такого наднационального образования, как Европейского сообщества союз. Финляндия и

\footnotetext{
${ }^{31}$ См.: Economides C. The relationship between international and domestic law. CDL-STD (1993)006. Strasbourg, 1993. P. 11; Осминин Б.И. Принятие и реализация государствами международных договорных обязательств. М., 2008. С. 51, 62, 110. ${ }^{32}$ См.: Economides C. Op. cit. P. 11.

${ }^{33}$ См.: Economides C. Projet d'etude comparative des solutions nationales sur la question des rapports entre le droit international et le droit interne et recommantations y relatives // Les rapports entre le droit international et le droit interne. Conseil de L'Europe. 1994. P. 78
}

Швеция являются членами ЕС и поэтому обязаны следовать требованиям нормативных актов, в том числе в сфере охраны окружающей среды, издаваемых Европарламентом и Еврокомиссией.

Экологическое право Европейского Сообщества включает в себя полномочия, предусмотренные первичным правом, и принятые на основании этих полномочий источники вторичного права ${ }^{34}$. Компетенция EC в сфере охраны окружающей среды основана на статьях 2, 3, 174 - 176 Договора об образовании Европейского сообщества (первичное право) $)^{35}$. В силу особой роли судебного прецедента в системе права Европейского Сообщества, положения первичного права применяются в интерпретации, отраженной в решениях судов (Суд ЕС, Суд первой инстанции и специализированные судебные палаты) $)^{36}$. Полномочия Европейского сообщества по разработке и принятию вторичного права основаны на указанных выше положениях первичного права. На их основании органы Европейского Сообщества принимают нормативные акты, которые в зависимости от формы обладают разными юридическими свойствами.

Наиболее важными из них С.Ю. Кашкин считает регламенты, директивы и рамочные соглашения ${ }^{37}$. Регламенты в силу статьи 249 Договора об образовании Европейского Сообщества имеют общее действие, обязательны в полном объеме и подлежат прямому применению во всех государствах-членах. В силу статьи 249 указанного Договора директивы имеют обязательную силу для государств-членов, которым они адресованы в отношении результата, которого требуется достичь, но оставляет на усмотрение каждого

\footnotetext{
$34 \mathrm{O}$ классификации источников права Европейского Сообщества см. подроб: Право Европейского Союза / Под общ. ред. С.Ю. Кашкина. М.: Юрайт, 2011. С. 140 - 177.

${ }_{35}$ См.: Кремер Л., Винтер Г. Экологическое право Европейского союза : пер. с нем. / Отв. ред. О.Л. Дубовик. М.: Городец, 2007. С. 10 - 11. Некоторые исследователи считают, что к основным положениям первичного права также относятся статьи 4, 5 и 95 Договора об образовании Европейского Сообщества. См. подроб.: Право Европейского Союза / Под общ. ред. С.Ю. Кашкина. М.: Юрайт, 2011. С. 849 - 853.

${ }^{36}$ См.: Европейское право: учеб. / Отв. ред. Л.М. Энтин. М.: Норма, 2005. С. $113-114$.

${ }^{37}$ См.: Право Европейского Союза / Под общ. ред. С.Ю. Кашкина. М.: Юрайт, 2011. С. 148.
} 
государства выбор формы и способов достижения такого результата. Согласно требованиям директив все правовые акты, принятые в целях трансформации конкретной директивы должны содержать ссылку на нее. Данное предписание в отношении директив введено в целях обеспечения единообразного толкования правовых актов национальными судами в соответствии с директивой, во исполнение которой они приняты ${ }^{38}$. По мнению специалистов в области европейского экологического права именно директивы являются наиболее регулярно применяемым в экологическом праве Европейского Сообщества видом нормативного правового акта, поскольку содержательно оно является в широком смысле «упорядочивающим правом». ${ }^{39}$

В силу изложенного и Финляндия, и Швеция, которые в последнее время весьма активно осуществляющие упорядочивание внутреннего законодательства в сфере охраны окружающей среды, при принятии актов, направленных на охрану окружающей среды, осуществляют одновременно инкорпорацию правовых актов Европейского Сообщества ${ }^{40}$. Так, например, 1118 Закона об охране окружающей среды Финляндии 2000 года ${ }^{41}$ coдержит ссылки на 34 директивы Совета Европы ${ }^{42}$,

\footnotetext{
${ }^{38}$ Речь в данном случае идет принципе «лояльной интерпретации», сформулированном Судом Европейских сообществ. См.: Дело 14/83 «Van Colson» [1984] // ECR 1981.

${ }^{39}$ См.: Кремер Л., Винтер Г. Экологическое право Европейского союза : пер. с нем. / Отв. ред. О.Л. Дубовик. М.: Городец, 2007. C. $32-34$.

${ }^{40} \mathrm{~B}$ отечественной теории государства и права принято различать консолидацию (объединение актов без изменения их содержания) и кодификацию (объединение актов, предусматривающее его пересмотр по существу) (см.: Общая теория государства и права. Т. 2 / Под ред. М.Н. Марченко. М.: Зерцало, 2001. С. 383 - 389). В то же время представители зарубежной доктрины рассматривают консолидацию как частный случай кодификации (см.: Кабрияк Р. Кодификации. М.: Статут, 2007. С. 95 - 109). - Прим. автора.

${ }^{41}$ Ympäristönsuojelulaki 86/2000 annettu Helsingissä 4 päivänä helmikuuta 2000. http://www.finlex.fi/fi /laki/alkup/ 2000/20000086.

${ }^{42}$ См., напр.: Council Directive 96/61/EC of 24 September 1996 concerning integrated pollution prevention and control // OJ L 257. 1996. P. 0026 - 0040; Council Directive 86/280/EEC of 12 June 1986 on limit values and quality objectives for discharges of certain dangerous substances included in List I of the Annex to Directive 76/464/EEC // OJ L 181. 1986. P. 0016 - 0027.
}

2 совместных директивы Европарламента и Совета Европы ${ }^{43}$ и одно решение Совета Европы.

Отметим, что данный Закон содержит многочисленные оговорки, предоставляющие Государственному Совету (правительства) Финляндии полномочия издавать отдельные акты делегированного законодательства (постановления) в исполнение законодательных предписаний (Раздел 2). Помимо этого в силу 16 указанного Закона в редакции 2005 года Государственный Совет может в целях выполнения соответствующих актов Европейского Сообщества и международных обязательств Финляндии издавать постановления, устанавливающие:

1) сроки действия и условия пересмотра разрешений, устанавливающих права на природопользование, а также условий, содержащихся в таких разрешениях;

2) обязанности оператора предоставлять властям информацию, обязанность предоставления которой установлена постановлениями, в отношении химикатов, использующихся в ходе осуществления деятельности, представляющей угрозу загрязнения, выбросов или отходов, образующихся или получаемых в ходе осуществления деятельности;

3) другие требования, необходимые для предотвращения загрязнения окружающей среды аналогичные требованиям, предусмотренным разделами $1-15$.

В ходе систематизации законодательства об охране окружающей среды Швеции, в результате которой в 1998 году был принят Кодекс окружающей среды Швеции ${ }^{44}$, также использованы отсылки к нормативным правовым актам Европейского Сообщества и международным договорам. В

\footnotetext{
${ }^{43}$ CM.: European Parliament and Council Directive 94/63/EC of 20 December 1994 on the control of volatile organic compound (VOC) emissions resulting from the storage of petrol and its distribution from terminals to service stations // OJ L 365. 1994. P. 0024 - 0033; Directive 97/68/EC of the European Parliament and of the Council of 16 December 1997 on the approximation of the laws of the Member States relating to measures against the emission of gaseous and particulate pollutants from internal combustion engines to be installed in non-road mobile machinery // OJ L 059. 1998. P. 0001 - 0086.

${ }^{44}$ См.: Miljöbalk (1998:808) // SFS. nr: 1998:808; Lag (1998:811) om införande av miljöbalken // SFS. nr: 1998:811 (версия на английском языке в издании: Miljöbalk (1998:808). Departementsserie. 2000:61. 186 s.).
} 
основном такие отсылки менее многочисленны ${ }^{45}$, чем в нормативных актах Финляндии. В Кодексе окружающей среды Швеции они сделаны:

а) к директивам, устанавливающим запрет на использование отдельных видов пестицидов и топлива (§14 и 22 Части 14 Кодекса окружающей среды) и правила организации территориальной охраны окружающей среды (§28 Части 7 Кодекса окружающей среды);

б) регламентам ЕС как таковым в Разделе 5 «Надзор»;

в) конкретным регламентам ЕС (в частности, в сфере обращения с отдельными видами опасных веществ, редкими видами животных и растений) в Разделе 6 «Санкции» ${ }^{46}$.

Правовые основания применения экологических директив и регламентов Европейского Сообщества в Норвегии отличаются от Финляндии и Швеции, поскольку Норвегия не является членом Европейского сообщества. Все указанные страны являются также участниками Соглашения о Европейском экономическом пространстве ${ }^{47}$, которое было заключено 2 мая 1992 г. в г. Порто (Португалия) и вступило в силу 1 января 1994 г. Соглашение о ЕЭП позволило распространить на европейские государства, формально не являющиеся членами Европейских сообществ и Европейского экономического пространства, правовой режим

${ }^{45}$ См., напр.: Директива 92/43/ЕЕС Совета Европы от 21 мая 1992 г. о сохранении природного ареала распространения для диких животных и растений; Директива Совета Европы 79/409/ЕЕС от 2 апреля 1979 г. о сохранении видов птиц, живущих в дикой природе; Директива Совета Европы 91/414/ЕЕС от 15 июля 1991 г. о запуске в обращение средств по защите растений; Директива Европейского парламента и Совета Европы 98/8/ЕС от 16 февраля 1998 о запуске в обращение средств для уничтожения вредителей; Регламент Совета Европы (EEC) 2455/92 от 23 июля 1992 г. относительно экспорта и импорта отдельных опасных химикатов; Регламент Совета Европы (ЕЕС) 3093/94 от 15 декабря 1994 г. об озоноразрушающих веществах; Регламент Совета Европы (EEC) 338/97 о защите экземпляров диких видов животных и растений посредством контроля торговли; Регламент Совета Европы (ЕEC) N 259/93 от 1 февраля 1993 г. по надзору и контролю за доставкой отходов в Европейское сообщество и из него.

${ }^{46}$ Описание структуры Кодекса окружающей среды Швеции см. в: Бринчук M.M., Редникова T.B. Кодекс окружающей среды Швеции // Экологическое право. 2010. № 6. С. 36 - 39.

${ }^{47}$ Agreement on the European Economic Area // OJ L 1. 1994. P. $3-522$. общего рынка, законодательство ЕС по вопросам свободного перемещения товаров, лиц, услуг и капиталов, а равно в смежных с ними сферах ${ }^{48}$.

В соответствии с Главой 3 «Окружающая среда» указанного Соглашения Договаривающиеся стороны при осуществлении деятельности в отношении окружающей среды преследуют такие цели, как ее охрана и рациональное использование природных ресурсов, а требования в сфере охраны окружающей среды являются составной частью других политик Договаривающихся сторон (ст. 73 Соглашения). Приложение $\mathrm{XX}^{49}$ к указанному соглашению содержит перечень обязательных экологических предписаний и более чем 170 директивам, регламентам и постановлениям Европейского Сообщества обязательного характера и более 10 актам, рекомендованным к применению сторонами. Например, директива Совета Европы относительно содержания диких животных в зоопарках 1999/22/EC Е0 $^{50}$ ба инкорпорирована в национальное законодательство Финляндии путем внесения соответствующих изменений в Закон о защите животных 1996/247 ${ }^{51}$. В Швеции совместная директива Совета Европы и Европарламента 2008/50/ЕС о качестве окружающего воздуха и более чистом воздухе в Европе ${ }^{52}$ была инкорпорирована в национальное право постановлением правительства (Государственного Совета) Швеции «О качестве воздуха» 2010:477.

Таким образом, акты экологического права Европейского Сообщества проходят две стадии трансформации. Первым этапом является признание таких актов обязательными для стран-участниц Европейского экономического пространства (ЕЭП). Вторым этапом является трансформация

\footnotetext{
${ }^{48}$ Blanchet T., Piipponen R., Westman-Clément M. The Agreement on the European Economic Area (EEA). A Guide to the Free Movement of Goods and Competition Rules. Oxford, 1994. 500 p. ${ }^{49}$ См.: Agreement on the European Economic Area - Annex XX - Environment - List provided for in Article 74 // OJ L 001. 1994. P. 0494 - 0500; Decision of the EEA Joint Committee No 122/2011 of 21 October 2011 amending Annex XX (Environment) to the EEA Agreement // OJ L 341. 2011. P. 87 - 87.

${ }^{50}$ Council Directive 1999/22/EC of 29 March 1999 relating to the keeping of wild animals in zoos // OJ L 94. 1999. P. $24-26$.

${ }^{51}$ Cм.: Eläinsuojelulaki 4.4.1996/247.

${ }^{52}$ Directive 2008/50/EC of the European Parliament and of the Council of 21 May 2008 on ambient air quality and cleaner air for Europe // OJ L. 152. 2008. P. 1 - 44.
} 
требований таких актов непосредственно в национальное право посредством материальной инкорпорации.

Очередная оценка уровня выполнения Норвегией своих экологических обязательств выполнялась под эгидой Организации экономического сотрудничества и развития (ОЭСР) констатировала, что данная страна успешно интегрирует акты экологического права Европейского Сообщества в национальное законодательство. Так, например, норвежский перечень опасных веществ включает 3500 наименований, сформированный в соответствии с Приложением 1 к Директиве 67/548/EEC Совета Европы о гармонизации законов, правил и административных процедур относительно классификации, упаковки и маркировки опасных веществ ${ }^{53}$. Отметим, что трансформация указанного Приложения осуществлена путем материальной инкорпорации его текста в Закон о маркировке опасных веществ 1981 года. При этом в ряде случае Норвегия (как и Швеция), предпочитает сохранять более высокие, по сравнению с европейскими, национальные стандарты. ${ }^{54}$

Примечательно, что в тех случаях, когда международные обязательства вступают в конфликт с национальными, в основном экономическими, интересами, все указанные страны принимают прагматичные решения в пользу последних. Показателен в этом смысле пример Норвегии в сфере сокращения выбросов и охраны морских млекопитающих.

В 1989 году Стортинг объявил о необходимости снижения выбросов углекислого газа на национальном уровне. Это предполагало введение новых мер регулирования в нефтегазовом секторе, сельском хозяйстве и на транспорте. В 1995 году правительство Норвегии решило не заниматься данным вопросом в принципе по причине «недостижимости поставленных целей». ${ }^{55}$ Несмотря на международные протесты, Норвегия

\footnotetext{
${ }^{53}$ Council Directive 67/548/EEC on the approximation of laws, regulations and administrative provisions relating to the classification, packaging and labelling of dangerous substances // OJ. 196.1967. P. 1.

${ }^{54}$ CM.: OECD Environmental Performance Reviews: Norway, 2011. OECD Publishing, 2011. Р. 79, 85, 144 и посл.

${ }^{55}$ Cм.: Heidar K. Norway: elites on trial. Westview Press, 2001. P. $127-128$.
}

в 1990-е годы приняла решение возобновить добычу китов на том основании, что с точки зрения устойчивого развития данный промысел «является устойчивым» ${ }^{56}$.

В Швеции при реализации концепции устойчивого развития в национальном законодательстве экологическим соображениям не всегда отдается приоритет по сравнению с экономической составляющей данной концепции. Кодекс окружающей среды Швеции 1998 г. содержит положения, согласно которым нормативы качества окружающей среды (environmental quality standards) должны устанавливать уровень загрязнения или других негативных воздействий, которые не создают значительного риска ущерба здоровью человека и окружающей среды ( 2 Части 5 Кодекса окружающей среды Швеции). Эксперты отмечают, что на практике данная установка не реализована. В обществе экологические нормативы воспринимаются через призму экономического роста и социального развития. В итоге, показатели нормативов качества устанавливаются исходя из прагматических соображений и предусматривают только такие показатели, превышение которых крайне опасно. ${ }^{57}$ Финляндия считает, что окружающая среда и торговля должны регулироваться международным правом «на одном уровне» ${ }^{58}$.

Таким образом, во всех рассматриваемых нами здесь странах для трансформации положений международных договоров в национальную систему требуется материальная (Норвегия, Швеция) или формальная (Финляндия) инкорпорация. Анализ существующих источников конституционного права Норвегии, Финляндии и Швеции ${ }^{59}$ и соответ-

\footnotetext{
${ }^{56}$ См.: Heidar K. Norway: elites on trial. Westview Press, 2001. P. $128,147$.

${ }^{57}$ Cм: OECD Environmental Performance Reviews: Sweden 2004. OECD Publishing, 2004. P. $100-101$.

${ }^{58}$ CM.: OECD Environmental Performance Reviews: Finland 2009. OECD Publishing, 2009. P. 153.

${ }^{59}$ См.: Конституция Норвегии (с поправками на 23 июля 1995 г.) (электронный ресурс: http://www.norge.ru/constitusia/); Конституция Финляндии (принята в г. Хельсинки 11 июня 1999 года). Хельсинки: Министерство юстиции, 1999. 35 с.; Конституция Швеции (Форма правления). Принята 27 февраля 1974 г. / Пер. со шведского М.А. Могуновой. М.: Норма - Инфра-М, 1999. С. $701-728$.
} 
ствующей литературы ${ }^{60}$ показывает, что принятие международных обязательств указанными странами в сфере охраны окружающей среды подчиняется общим правилам принятия ими международных обязательств. Это осуществляется путем признания международных обязательств и придания им статуса национального права актами национального права.

Во всех странах Северной Европы допускается придание нормам международных договоров юридической силы в национальном праве не только законодательными актами, но и нормативными правовым актами органов исполнительной власти. Это имеет место в случае заключения договоров, не требующих внесения изменений в законодательные акты. В этом случае положения международного договора имеют силу нормативных правовых актов органов исполнительной власти ${ }^{61}$. Естественно, что инкорпорированные таким образом нормы имеют подчиненный характер по отношению к нормам, инкорпорированным законодательными актами ${ }^{62}$.

Устойчивость инкорпорированных норм при последующих изменениях актов инкорпорации осуществляется посредством толкования норм национального права способами, обеспечивающими соответствие норм национального права принятым международным обязательствам.

Комиссия по международному праву $\mathrm{OOH}$ указала на то, что государство - «это реальная организованная целостность, однако признание этой “реальности” не означает отрицания элементарной истины, что государство как таковое не способно действовать физически. Следовательно, в конечном счете, поведение, рассматриваемое как “акт государства", не может быть ничем иным, кроме как действием или отсутствием действия, физически реализованным человеком или сообществом людей» ${ }^{63}$. Поэтому в ряде случаев для того, чтобы превратить цели, заложенные в нормах международного права, в реальные действия или, в ряде случаев, бездействие находящихся под государственной юрисдикцией органов и физических лиц, необходимо принятие определенных мер на внутригосударственном уровне.

Поэтому, несмотря на активное участие стран Северной Европы в процессе формирования системы международных договоров с самого начала ее создания ${ }^{64}$, данные договоры с формально-юридической точки зрения не являются источниками права в этих странах. Это связано с тем, что положения международных договоров подлежат инкорпорации в источники национального права. Это касается и источников экологического права такого наднационального образования, как Европейское сообщества ${ }^{65}$, положения которых проходят процедуру инкорпорации прежде, чем приобретут обязательность в национальном праве.

\section{Библиография:}

1. Дубовик О.Л., Кремер Л., Любе-Вольфф Г. Экологическое право : Учеб. М.: Эксмо, 2005.

2. Исаев М.А. Механизм государственной власти в странах Скандинавии. М. : Городец, 2004.

3. Исаев М.А. Основы конституционного строя Норвегии / Науч. ред. Чеканский А.Н. М.: Муравей, 2001.

\footnotetext{
${ }^{60}$ См.: Могунова М.А. Скандинавский парламентаризм. Теория и практика. М.: РГГУ, 2001. 347 с.; Могунова М.A. Государственное право Финляндии. М.: Городец, 2005. 368 с.; Могунова М.А. Государственное право Швеции. М.: Норма, 2009. 384 с.; Исаев М.A. Механизм государственной власти в странах Скандинавии. М. : Городец, 2004. 398 с.; Исаев М.A. Основы конституционного строя Норвегии / Науч. ред. Чеканский А.Н. М.: Муравей, 2001. 213 с.

${ }^{61}$ См.: Economides C. The relationship between international and domestic law. CDL-STD (1993)006. Strasbourg, 1993. P. 12.

${ }^{62}$ См., напр.: Country Reports. Sweden // Treaty Making Expression of Consent by States to be Bound by a Treaty. Hague, 2001. P. 207.
}

\footnotetext{
${ }^{63}$ Doc. UN A/51/10. P. 183.

${ }^{64}$ См. Приложение 3.

${ }^{65}$ Подробнее о системе источников экологического права Европейского сообщества см.: Дубовик О.Л., Кремер Л., Любе-Вольфф Г. Экологическое право : Учеб. М.: Эксмо, 2005. С. 113 - 272; Кремер Л., Винтер Г. Экологическое право Европейского союза : пер. с нем. / Отв. ред. О.Л. Дубовик. М.: Городец, 2007.
} 
4. Могунова М.А. Скандинавский парламентаризм. Теория и практика. М.: РГГУ, 2001.

5. Могунова М.А. Государственное право Финляндии. М.: Городец, 2005.

6. Могунова М.А. Государственное право Швеции. М.: Норма, 2009.

\section{References (transliteration):}

1. Blanchet T., Piipponen R., Westman-Clément M. The Agreement on the European Economic Area (EEA). A Guide to the Free Movement of Goods and Competition Rules. Oxford, 1994. 500 p.

2. Economides C. The relationship between international and domestic law. CDL-STD (1993)006. Strasbourg, 1993.

3. Economides C. Projet d'etude comparative des solutions nationales sur la question des rapports entre le droit international et le droit interne et recommantations y relatives // Les rapports entre le droit international et le droit interne. Conseil de L'Europe. 1994. P. 78.

4. OECD, Environmental Performance Reviews: OECD Publishing, 2011, 202 p. 